\title{
A new synonym and description of two new species of Portanus (Hemiptera, Cicadellidae, Xestocephalinae) from Brazil and Bolivia
}

\author{
Adenomar N. Carvalho' \& Rodney R. Cavichioli
}

\begin{abstract}
1. Instituto de Biodiversidade e Florestas, Universidade Federal do Oeste do Pará, Rua Vera Paz, s/n, Salé, 68035-1 10 Santarém, PA, Brazil. (adenomarc@yahoo.com.br) 2. Departamento de Zoologia, Universidade Federal do Paraná, Caixa Postal 19020, 81531-990 Curitiba, PR, Brazil.
\end{abstract}

Received 29 September 2015.

Accepted 25 August 2016.

ZOOBANK: http://zoobank.org/urn:Isid:zoobank.org:pub:5444C157-7500-4F61-9314-78064704CA64

DOI: 10.1590/1678-4766e2017001

ABSTRACT. One leafhopper species of the genus Portanus Ball, 1932 is synonymized: P. spinosus is considered junior synonym of $P$. hasemani. In this paper, we offer the redescription of $P$. hasemani as well as description of two new species of Portanus, based on specimens from the type series of Scaphoideus punctulatus Osborn, 1923 (= P. hasemani): P. bifurcus sp. nov. and P. delsara sp. nov. The descriptions are based on features from the external morphology and male genital structures. Comparisons of the two new taxa with the remaining Portanus species are provided.

KEYWORDS. Auchenorrhyncha, Leafhopper, Neotropical Region, Taxonomy.

RESUMO. Uma nova sinonímia e descrição de duas espécies novas de Portanus (Hemiptera, Cicadellidae, Xestocephalinae) do Brasil e Bolívia. Uma espécie de cigarrinha do gênero Portanus Ball, 1982 é sinonimizada: P. spinosus é considereada sinônimo júnior of $P$. hasemani. Neste artigo, é realizada a redescrição de $P$. hasemani, bem como a descrição de duas espécies novas de Portanus, com base em espécimes da série tipo de Scaphoideus punctulatus (= P. hasemani): P. bifurcus sp. nov. e P. delsara sp. nov. As descrições foram baseadas na morfologia externa e estruturas da genitália masculina. Comparações dos táxons novos com as demais espécies de Portanus são fornecidas.

PALAVRAS-CHAVE. Auchenorrhyncha, Cigarrinha, Região Neotropical, Taxonomia.

Portanus was established by BALL (1932) based on the type-species Scaphoideus stigmosus Uhler, 1895. The author also included in it Scaphoideus longicornis Osborn, 1923. That new genus has been associated to the Deltocephalinae genera Scaphoideus Uhler, 1889 and Osbornellus Ball, 1932 due to its general appearance and venation (BALL,1932).

OMAN (1936) revised the genera of American Bythoscopinae and the South America Iassinae and transferred two additional Scaphoideus species to Portanus: Scaphoideus boliviensis Baker, 1923 wherein synonymized as S. bicolor Osborn, 1923 nec S. bicolor Ball, 1909, and S. hasemani Baker, 1923, with S. punctulatus Osborn, 1923 nec S. punctulatus Melichar, 1903 (CARVAlHo \& CAVICHIOLI, 2001). Later, LiNNAVUORI (1959) transferred two additional Scaphoideus species to this genus. Until 2009, one more species was transferred to Portanus and 44 new species were described (De Souza \& TAKIYA, 2014 and CARVALHO, 2012), so the genus then included 54 described species, all from the Neotropical region. CARvalHo \& CAVICHIOLI (2009) erected second genus in Portanini, Poraportanus Carvalho \& Cavichioli, 2009 and nine Portanus species were transferred to Paraportanus.

The first author of this paper in your doctoral thesis reviewed Portanus. He studied the type series of the
Scaphoideus punctulatus Osborn, 1923 (=S. hasemani Baker, 1923) and compared the male holotype with the paratypes and concluded that three of the five paratypes differed both in the holotype staining pattern as male genitalia. This way, two new species should be included in Portanus. At the time, he also studied the holotype of Portanus spinosus DeLong, 1982 and considered this species as junior synonym of $P$. hasemani (Baker, 1923).

In this paper, $P$. spinosus is considered as junior synonym of $P$. hasemani and two new species of Portanus are described and illustrated from specimens collected in Brazil and Bolivia. Notes comparing the two new taxa with the remaining Portanus species are provided.

\section{MATERIAL AND METHODS}

For the analysis of genital structures, the abdomen was

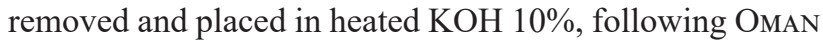
(1949). Softened genitalia were washed for 5 to 10 minutes in hot water and placed on a concave slide with glycerin to maintain the desired position for the illustrations. Dissected structures were kept in microvials with glycerin and pinned together with the specimen. Illustrations were made using camera lucida attached to a stereoscopic microscope. 
The terminology follows Young $(1968,1977)$ and BLOCKer \& TRIPLEHORN (1985), except for the head structures, which follows HAMILTON (1981). Information on specimen labels were transcript as follows: a slash [/] separates the rows and two slashes [//] the labels. Specimens studied are deposited in the Carnegie Museum of Natural History, Pittsburgh, USA (CMNH) and Ohio State University Collection, Columbus, USA (OSUC).

\section{RESULTS}

\section{Portanus hasemani (Baker, 1923)}

(Figs 1-6)

Scaphoideus hasemani BAKER, 1923:532

Scaphoideus punctulatus OsBORN, 1923:37

Portanus hasemani Oman, 1936:370

Portanus spinosus DeLong, 1982:392 Syn. nov.

Diagnosis. Pygofer lobe with posterior margin rounded (Fig. 2), dorsocaudal margin with tooth turned inwardly; aedeagus slender, curved and elongate with apex bearing three spiniform processes directed ventrally (Figs 5,6 ), median portion serrate just before slender, pointed, apical tip in apical view.

Measurements (mm). Male: body length, 4.50. Female: not examined.

Coloration. Head and thorax brown; crown and venter brownish-yellow. Pronotum (Fig. 1) dark brown with several ivory speckles. Scutellum yellowish with basal angles brown (Fig. 1). Forewings translucent brown; veins marked with dark brown with small white spots; two creamy white regions beside the costal cell; apex completely dark brown.

Redescription. Crown (Fig. 1), in dorsal view, produced anteriorly and bluntly angled; with transocular width longer than crown median length; frontogenal sutures reaching ocelli. Pronotum as wide as transocular width; lateral margins angulate; dorsopleural carina inconspicuous; posterior margin straight; texture smooth with transverse striae. Scutellum (Fig. 1) shagreen. Forewings with two closed anteapical cells, inner anteapical cell open; median cell slightly longer than adjacent ones; third apical cell with apex broad, fourth apical cell subtriangular. Appendix absent. Other characters as in generic description (CARVALHO \& Cavichioli, 2003; De Souza \& TakiYa, 2014).

Male genitalia. Pygofer lobe (Fig. 2), in lateral view, as long as high; posterior margin rounded; dorsocaudal margin with tooth turned inwardly; macrosetae distributed at dorsal half of lobe. Subgenital plates, in lateral view, extending posteriorly farther than pygofer apex; in ventral view (Fig. 3), with apical third slightly upturned; basal third with transverse unpigmented line; ventral surface of each subgenital plate with uniseriate robust macrosetae and many long and fine microsetae at apical half. Connective (Fig. 4), in dorsal view, Y-shaped; basiventral process short. Styles (Fig. 4), in dorsal view, with apical fourth wide and appearing bifid because of an elongate and robust preapical lobe; preapical region and apex of preapical lobe more sclerotized and sculptured; apex acute. Aedeagus (Fig. 5), in lateral view, curved and elongate with apex bearing three spiniform processes directed ventrally (Fig. 6); in apical view, median portion appearing serrate just before slender, pointed, apical tip. Gonopore apical.

Material examined. Prov.[incia] [Santa Rosa] Del Sara / Bol.[ivia] Steinbach / C. M. 5064 // Nov.[ember].1911 // Type // Scaphoideus / punctulatus / n. sp. Osb.[orn]. Paratypes: 1 male, Prov.[ince] [Santa Rosa] Del Sara / Bol. [ivia] Steinbach / C. M. 5064 // Para- / type. 1 male, Bahia / Brasil // 08.XII.1907 // Carn.[egie] Mus.[eum] / Acc1702 // Para- / type (CMNH). Bolivia; Santa Cruz [de La Sierra] / Don Foster / 21.VII.1980 // Bol - 124 // Holotype / Port. [anus] / spinosus / DeLong (OSUC).

Remarks. Uhler (1895) described Scaphoideus stigmosus from Santa Rosa del Sara, Bolivia (treated as a junior synonym of $P$. hasemani), not far from the type locality of $P$. spinosus DeLong, 1982, in Santa Cruz de la Sierra, Bolivia. We examined the specimens coupled with the descriptions and concluded that there are no characters which could delimit $P$. hasemani and P. spinosus. Moreover, the studied material does not exhibit any marked variation throughout the collection range, thereby enabling us to confidently treat $P$. spinosus as a junior synonym of $P$. hasemani.

\section{Portanus bifurcus sp. nov.}

(Figs 7-12)

http://zoobank.org/urn:1sid:zoobank.org:act:D450B948-996C4EBB-AFC4-55AD1DF20781

Diagnosis. Pygofer produced posteriorly with apical lobe acute, spine-like (Fig. 8); aedeagal apex with pair of elongate processes directed ventrally (Fig. 11), each with one basilateral branch directed ventrally (Fig. 12).

Measurements (mm). Male: total length 7.00. Female unknown.

Coloration. Head and thorax brown; venter brownishyellow. Crown and pronotum dark-yellow. Pronotum (Fig. 7) with several ivory speckles. Scutellum (Fig. 7) mostly ivory with paired, large dark lateral triangular areas at anterior half. Forewings translucent brown; veins marked with dark brown with small white spots; four hyaline regions on costal margin at apical half; apex completely dark brown.

Description. Crown (Fig. 7), in dorsal view, produced anteriorly with transocular width longer than crown median length; anterior margin slightly angulate; frontogenal sutures not reaching ocelli. Pronotum as wide as transocular width; lateral margins angulate; dorsopleural carina inconspicuous; posterior margin straight; texture smooth with transverse striae (Fig. 7). Scutellum shagreen. Forewings with three closed anteapical cells, median anteapical cell slightly longer than adjacent ones; third apical cell with apex broad, fourth 

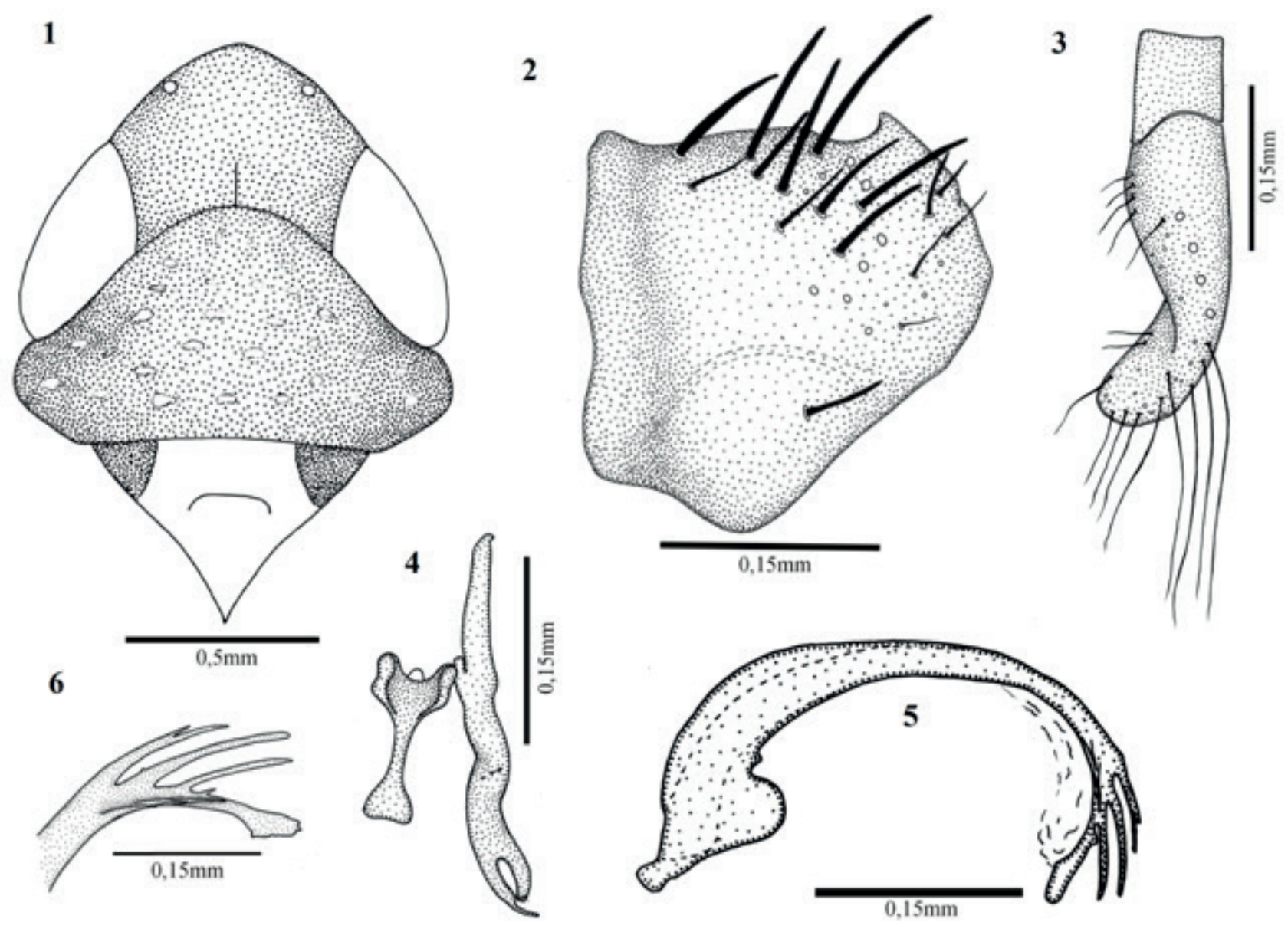

Figs 1-6. Portanus hasemani: 1, crown, pronotum and scutellum; 2, pygofer, lateral view; 3 , subgenital plate, ventral view; 4, connective and right style, dorsal view; 5 , aedeagus, lateral view; 6 , aedeagal apex, lateral view.

apical cell subtriangular. Appendix absent.

Male genitalia. Pygofer lobe (Fig. 8), in lateral view, longer than high, oblong; posterior margin straight; ventrocaudal margin with acute spine-like process; macrosetae on dorsal half of lobe. Subgenital plates (Fig. 8), in lateral view, extending posteriorly farther than pygofer apex; apical third slightly upturned; basal third with transverse unpigmented line; ventral surface of each subgenital plate with uniseriate robust macrosetae and many long and fine microsetae at apical half (Fig. 9). Connective (Fig. 10), in dorsal view, Y-shaped; basiventral process short. Styles (Fig. 10), in dorsal view, with apical fourth wide and forked, with internal branch apical fourth rounded. Aedeagus (Fig. 11), in lateral view, with shaft tubular and long, with a strong bend in basal fourth; dorsal apodemes absent; apex with pair of elongate processes directed ventrally, each with one basilateral branch directed ventrally (Fig. 12). Gonopore apical.

Type-material. Holotype: male, Ft. [Forte] Príncipe / Rio Guaporé / Brasil // 20.VIII.1909 // Carn.[egie] Mus. [eum] / Acc4043 // Para- / type [Scaphoideus punctulatus Osborn, 1923], CMNH. Paratype: 1 male, same label data as holotype, CMNH.

Etymology. The species epithet derives from the
Latin word bifurcus, meaning "bifurcated", in allusion to the aedeagal apex with pair of elongate and bifurcated processes directed ventrally.

Remarks. Portanus bifurcus sp. nov. is indistinguishable from many other Portanus species based on color pattern, being most similar to P. hasemani (Baker, 1923), P. uhleri Kramer, 1964, P. pictus Carvalho \& Cavichioli, 2001, and P. spinosus DeLong, 1982. However, it can be distinguished from these and other species by the characteristics given in the diagnosis, especially the well-developed aedeagal apex with pair of elongate processes, each with one basilateral branch directed ventrally.

\section{Portanus delsara sp. nov.}

(Figs 13-19)

http://zoobank.org/urn:lsid:zoobank.org:act:D30CC908-3B74-

$$
\text { 49C5-943A-CD344A7EBF83 }
$$

Diagnosis. Pygofer lobe with poster margin straight (Fig. 14), ventrocaudal margin with inner craw-like process extending dorsocaudally (Fig. 15); aedeagus elongate, with apical half curved dorsally with mouth-shaped opening in posterior margin, apex truncated (Fig. 19). 


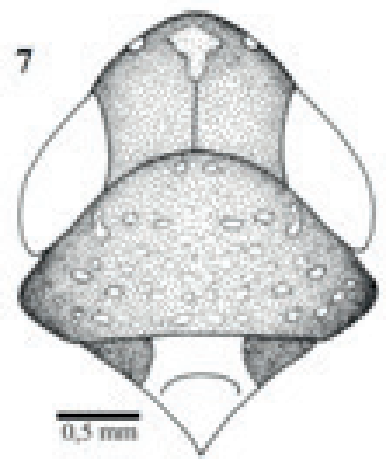

8
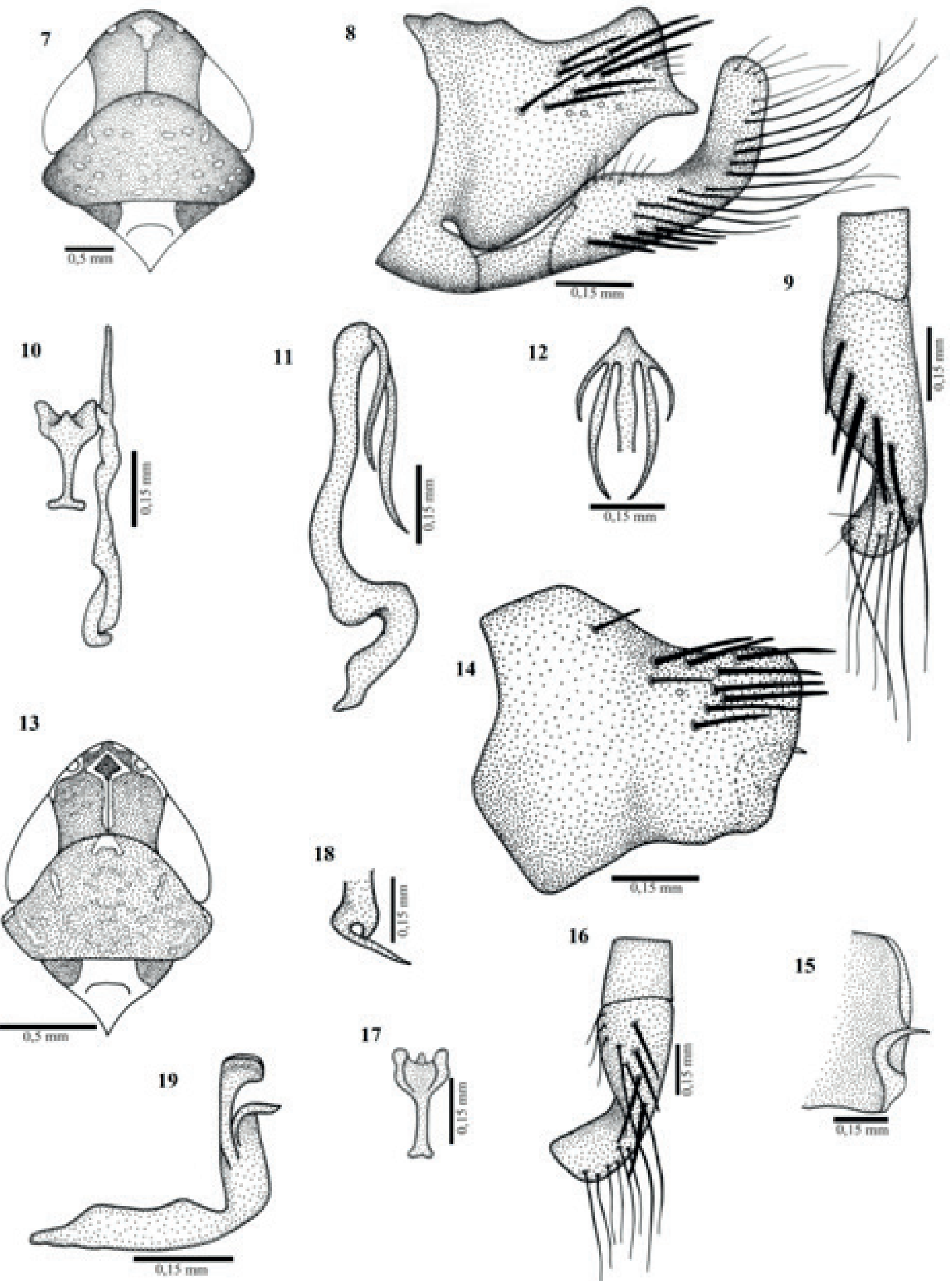

17
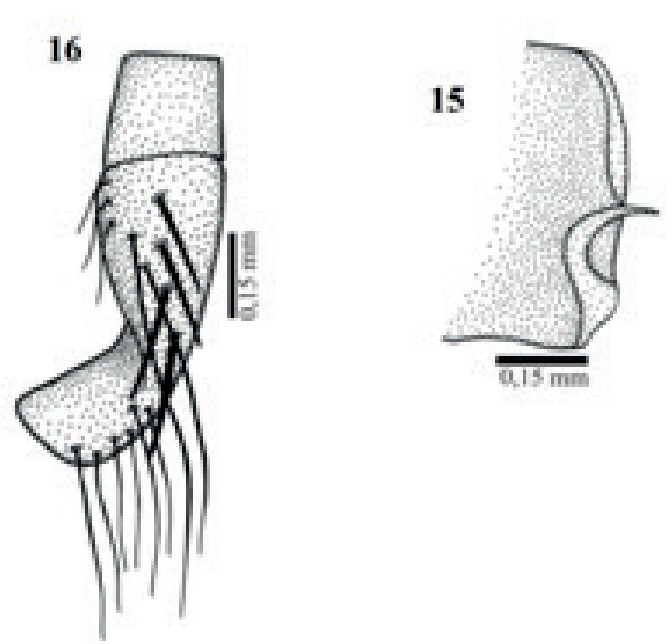

Figs 7-19. Portanus bifurcus sp. nov.: 7, crown, pronotum and scutellum; 8, pygofer, valve and subgenital plate, lateral view; 9 , subgenital plate, ventral view; 10, connective and left style, ventral view; 11, aedeagus, lateral view; 12, aedeagus, caudal view. Portanus delsara sp. nov.: 13 crown, pronotum and scutellum; 14, pygofer, lateral view; 15, pygofer, caudal view; 16, subgenital plate, ventral view; 17, connective, dorsal view; 18, style apex, dorsal view; 19, aedeagus, lateral view. 
Measurements (mm). Male: total length 5.00. Female unknown.

Coloration. Head and thorax light brown; venter brownish-yellow. Crown light brown (Fig. 13), with median line, apical triangular outline and two apical small spots, ivory. Pronotum light brown (Fig. 13) with several ivory speckles. Scutellum (Fig. 13) mostly ivory with paired, large dark lateral triangular areas at anterior half. Forewings translucent brown; veins marked with dark brown with small white spots; white regions on costal margin at apical half and apex of claval veins; apex completely dark brown with translucent areas on apical cells.

Description. Crown (Fig. 13), in dorsal view, produced anteriorly with transocular width longer than crown median length; anterior margin lightly angulate; frontogenal sutures not reaching ocelli. Pronotum as wide as transocular width; lateral margins angulate; dorsopleural carina inconspicuous; posterior margin straight; texture smooth with transverse striae. Scutellum smooth. Forewings with three closed anteapical cells, median anteapical cell slightly longer than adjacent ones; third apical cell with apex broad, fourth apical cell subtriangular. Appendix absent.

Male genitalia. Pygofer lobe (Fig. 14), in lateral view, longer than high; posterior margin straight; ventroapical margin with inner craw-like process, extending dorsocaudally (Fig. 15); macrosetae on dorsal half of lobe. Subgenital plates, in lateral view, extending posteriorly farther than pygofer apex; apical third slightly upturned; basal third with transverse unpigmented line; ventral surface of each subgenital plate with uniseriate robust macrosetae and many long and fine microsetae at apical half (Fig. 16). Connective (Fig. 17), in dorsal view, Y-shaped; basiventral process short. Styles (Fig. 18), in dorsal view, with apical fourth wide and forked, with internal branch elongate and acute. Aedeagus (Fig. 19), in lateral view, elongate; apical half curved dorsally with mouth-shaped opening in posterior margin; apex truncated; apodemes absent. Gonopore apical.

Type-material. Holotype: male, "Prov.[ince] Del Sara / Bol.[ivia] Steinbech / C. M. Acc 5064 // Feb.[ruary] / 1913 // Paratypus // Scaphoideus / punctulatus / n. sp. Osb.[orn] // Paratype / S. Punctulatus / Osb.[orn] / Carn.[egie] Mus. [eum] Ent.[omology]" (CMNH).

Etymology. The species epithet is a noun in apposition taken from the type locality.

Remarks. Portanus delsara sp. nov. is very similar to $P$. sagittatus Carvalho \& Cavichioli, 2004, both species sharing: (1) similar shape of ivory maculae on crown apex; and (2) ventroapical margins of male pygofer with inner craw-like process, extending dorsocaudally. However, the new species can be distinguished from the latter and other
Portanus species by its aedeagus elongate, with apical half curved dorsally with mouth-shaped opening in posterior margin, and apex truncated.

Acknowledgements. We are grateful to Chen Young $(\mathrm{CMNH})$, and Norman Johnson and Luciana Musetti (OSUC), who kindly provided on loan the material examined. We also thank anonymous reviewers for reading the manuscript and by suggestions.

\section{REFERENCES}

BAKer, C. F. 1923. Comparison of neotropical and paleotropical insect Faunae. Philippine Journal Science 23:531-532.

BALL, E. D. 1932. New genera and species of leafhoppers related to Scaphoideus. Journal of the Washington Academy of Sciences 22:9-19.

Blocker, H. D. \& Triplehorn, B. W. 1985. External morphology of leafhoppers. In: NAULt, L. R. \& Rodrigues, J. G. eds. The Leafhoppers and Planthoppers. New York, John Wiley \& Sons. 500p.

Carvalho, A. N. 2012. A new species of Portanus (Hemiptera, Cicadellidae, Xestocephalinae) from Brazil. Iheringia, Série Zoologia 102(4):423425.

Carvalho, A. N. \& Cavichioli, R. R. 2001. Portanus Ball: descrições de cinco espécies novas (Hemiptera, Auchenorryncha, Cicadellidae, Xestocephalinae) do Mato Grosso, Brasil. Revista Brasileira de Zoologia 18:855-867.

Carvalho, A. N. \& Cavichioli, R. R. 2003. Portanus Ball: descrições de dez espécies novas (Hemiptera, Cicadellidae, Xestocephalinae). Revista Brasileira de Entomologia 47:547-558

Carvalho, A. N. \& Cavichioli, R. R. 2009. Novo gênero e espécie de Portanini Linnavuori, e notas taxonômicas (Hemiptera, Cicadellidae, Xestocephalinae). Revista Brasileira de Entomologia 53(1):26-31.

Delong, D. M. 1982. New species of Xestocephalinae (Homoptera: Cicadellidae) from Mexico, Panama, Peru, and Brazil. Proceedings of the Entomological Society of Washington 84(2):391-396.

De Souza, S. P. \& Takiya, D. M. 2014. Description of two new species of Portanus Ball, 1932 (Hemiptera: Cicadellidae: Portanini) from Northeastern Brazil. Zootaxa 3857:444-450.

Hamilton, K. G. A. 1981. Morphology and evolution of the rhynchotan head (Insecta: Hemiptera, Homoptera). Canadian Entomologist 113:953-974.

LINNAVUORI, R. E. 1959. Revision of the Neotropical Deltocephalinae and some related subfamilies (Homoptera). Annual Zoology Society 'Vanamo' 20:45-51.

OMAN, P. W. 1936. A generic Revision of American Bythoscopinae and South American Jassinae. Bulletin of the University of Kansas 37:343-420.

Oman, P. W. 1949. The Nearctic leafhoppers (Homoptera: Cicadellidae), a generic classification and check list. Memoirs of the Washington Entomological Society 3:1-258.

Osborn, H. 1923. Neotropical Homoptera of the Carnegie Museum II. Annual Carnegie Museum 15:27-79.

UhleR, P. R. 1895. An enumeration of the Hemiptera-Homoptera of the Island of St. Vincent, W. I. Proceedings of the Zoology Society London 1895:55-84.

Young, D. A. 1968. Taxonomic study of the Cicadellinae (Homoptera: Cicadellidae) Part 1. Proconiini. Bulletin of the United States National Museum 261:1-287.

Young, D. A. 1977. Taxonomic study of the Cicadellinae (Homoptera: Cicadellidae) Part 2. New world Cicadellini and the Genus Cicadella. Bulletin of North Carolina Agricultural Experiment Station 239:11135 . 